\section{Nf2 gene inactivation in arachnoidal cells is rate-limiting for meningioma development in the mouse}

\author{
Michel Kalamarides, ${ }^{1}$ Michiko Niwa-Kawakita, ${ }^{1}$ \\ Hélène Leblois, ${ }^{2}$ Vincent Abramowski, ${ }^{1}$ \\ Michel Perricaudet, ${ }^{2}$ Anne Janin, ${ }^{3}$ \\ Gilles Thomas, ${ }^{1}$ David H. Gutmann, ${ }^{4}$ \\ and Marco Giovannini ${ }^{1,5}$
}

${ }^{1}$ INSERM U434, Fondation Jean Dausset-Centre d'Etude du Polymorphisme Humain, 75010 Paris, France; ${ }^{2}$ UMR1582 Institut Gustave Roussy, 94805 Villejuif, France; ${ }^{3}$ Laboratory of Pathology INSERM ERIT-M 0209, 75010 Paris, France; ${ }^{4}$ Department of Neurology, Washington University School of Medicine, St. Louis, Missouri 63110-1093, USA

Biallelic NF2 gene inactivation is common in sporadic and in neurofibromatosis type 2 (NF2)-related meningiomas. We show that, beginning at four months of age, thirty percent of mice with arachnoidal cell Cre-mediated excision of $N f 2$ exon 2 developed a range of meningioma subtypes histologically similar to the human tumors. Additional hemizygosity for p53 did not modify meningioma frequency or progression suggesting that Nf2 and p53 mutations do not synergize in meningeal tumorigenesis. This first mouse model initiated with a genetic lesion found in human meningiomas provides a powerful tool for investigating tumor progression and for the preclinical evaluation of therapeutic interventions.

Received January 25, 2002; revised version accepted March 27, 2002.

Meningioma is a common nervous system tumor that affects older adults and particularly women, often associated with significant morbidity (Louis et al. 2000). Though most lesions are benign grade I malignancies, a significant proportion demonstrate aggressive features. In this regard, meningiomas can invade brain tissue, recur after resection, and spread along the leptomeninges to involve multiple regions (Louis et al. 2000).

Individuals with neurofibromatosis type 2 (NF2) are at significantly elevated risk for developing meningiomas (Evans et al. 1992), suggesting that the NF2 gene might play a central role in regulating leptomeningeal cell proliferation. Biallelic inactivation of the NF2 gene has been identified in $30 \%-70 \%$ of sporadic meningiomas, leading to loss of expression of the NF2 gene product, merlin or schwannomin (Gutmann et al. 1997). In addition, NF2 inactivation is likely an early event in sporadic menin-

[Key Words: NF2; meningioma; tumor suppressor gene; adenoviral vector; conditional knockout mice; Cre/loxP]

${ }^{5}$ Corresponding author.

E-MAIL marco@cephb.fr; FAX 33-1-5372-5192.

Article and publication are at http://www.genesdev.org/cgi/doi/10.1101/ gad.226302. gioma pathogenesis and is observed as frequently in grade I meningiomas as it is in high-grade tumors (Perry et al. 2000).

Current animal models of meningiomas have relied on implantation of human meningioma cells in immunocompromised mice (McCutcheon et al. 2000). Grade I meningiomas grow slowly in vitro and rarely survive as explants in vivo. Only a few high-grade malignant human meningioma cell lines grow as explants in immunocompromised mice in vivo, with tremendous variability and success. Based on these limitations, the availability of an in vivo model system in which meningiomas arise from normal arachnoidal cells would be a major advance.

Although cancer prone, heterozygous $N f 2$ mutant mice $\left(N f 2^{+/-}\right)$do not develop meningioma (McClatchey et al. 1998; Giovannini et al. 2000), but rather die with osteosarcomas and other tumor types not found in humans with NF2. We demonstrated previously that Nf2 inactivation is a rate-limiting step in murine Schwann cell tumorigenesis using the $P O$ promoter to express Cre recombinase in Schwann cells (Giovannini et al. 2000). Remarkably, meningioma was not observed in these mice, suggesting that Cre recombinase expressed from a Schwann cell-specific promoter does not affect meningioma progenitor cells. Electron microscopy and immunophenotypic studies show that meningiomas originate from arachnoidal cells of the meningeal coverings of the brain and spinal cord that are in contact with the cerebrospinal fluid (CSF) (Tohma et al. 1992).

An alternative approach for the delivery of Cre recombinase into specific target tissues involves the use of a recombinant adenovirus (adCre) (Wang et al. 1996). This approach also has the advantage of targeting the initiating genetic lesion (in this case, homozygous inactivation of Nf2) to a small population of susceptible cells, which is likely to model human cancer more accurately than when all of the cells in a target tissue are mutated (Zhang et al. 2001).

In this report, we describe the first mouse model for familial and sporadic meningioma. Mice with conditional Nf2 gene inactivation in leptomeningeal cells were prone to the development of meningiomas that were observed on two distinct genetic backgrounds (wild-type and heterozygous mutant p53) with no differences in tumor grade or histological appearance. Thus, we show that Nf2 loss in arachnoidal cells, but not loss of $p 53$, is rate-limiting for meningioma development, confirming the critical role of the $N f 2$ gene as growth regulator for leptomeningeal cell.

\section{Results and Discussion}

Delivery of adenoviral vectors to leptomeninges of newborn mice

To model human NF2-related and sporadic meningioma in the mouse, we have targeted Cre recombinase to the leptomeninges by direct injection of adCre into the CSF of $N f 2^{\text {flox2/flox } 2}$ mice. To examine the distribution of virally infected cells with respect to the injection site, we used a recombinant adenovirus encoding the lac $Z$ gene driven by the CMV promoter (adlacZ) (Stratford-Perricaudet et al. 1992; Fig. 1A,B). Histochemical analysis of 
A
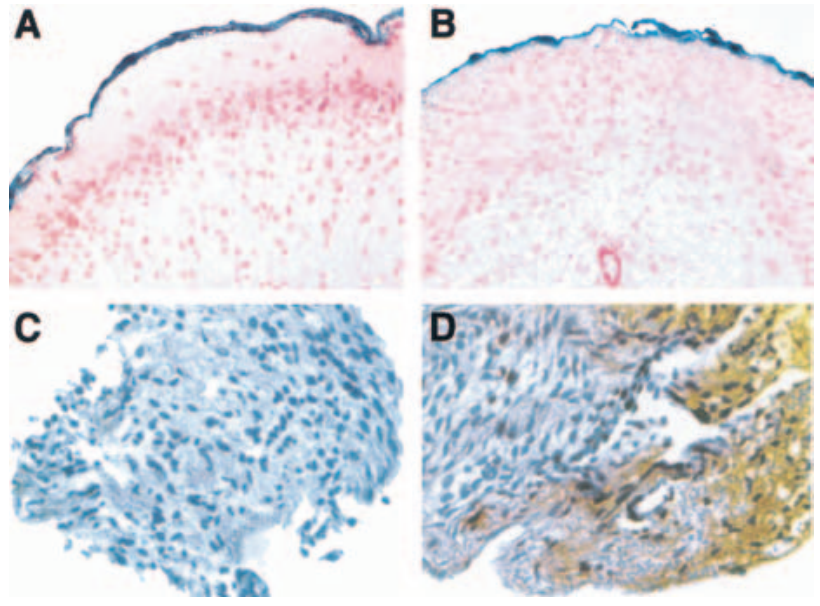

Figure 1. Delivery of adenoviral vectors to leptomeninges of newborn mice. $(A, B)$ Detection of $\beta$-galactosidase activity four days after intra-CSF injection of adlacZ in newborn mice. X-Gal staining demonstrates extensive transduction and high expression levels of $1 a c Z$ in the leptomeninges of the brain (transorbital and subdural) and the spinal cord (subdural). Microscopic examination of the leptomeninges demonstrates transduction of cells in the arachnoid and pia mater surrounding the cerebral cortex $(A)$, and after subdural adlac $Z$ infusion also in the leptomeninges covering the spinal cord $(B)$. Immunohistochemical analysis of leptomeninges dissected at the adCre injection site with anti-merlin WA30 polyclonal antibodies showing merlin loss in arachnoidal cells of transorbital adCre; $N f 2^{\text {flox } 2 / f l o x 2}$ mice $(C)$; leptomeninges of noninjected $N f 2^{\text {flox2/flox2 }}$ mice exhibit merlin staining $(D)$.

$\beta$-galactosidase activity from tissues of pups injected by the transorbital approach revealed numerous positively stained cells throughout tissues surrounding the injection area, the leptomeninges covering the right trigeminal nerve, the arachnoid layer on the ventral face of the right cerebral frontal lobe (Fig. 1A), and bones of skull base and right orbit. After adlac $Z$ subdural infusion, the leptomeninges (arachnoid and pia mater) covering the right frontal cerebral cortex, the skull, and surrounding the spinal cord showed positively stained cells, indicating wide spatial diffusion of adlacZ through the CSF circulation (Fig. 1B). Despite the nonstereotactic handlings, the transorbital and subdural approaches allowed good reproducibility of the spatial distribution of the adenoviral solution: After X-Gal staining, a blue precipitate was observed in all 16 (8 transorbital, 8 subdural) adlacZ injected newborn mice, both in the vicinity of and distant from the injection site. Mortality was $<1 \%$ of the injected pups. To investigate whether adenovirus expressing functional Cre protein could inactivate Nf2 in leptomeningeal cells in vivo, we constructed an E1deleted adCre recombinant adenovirus and used $N f 2^{\text {flox } 2 / f l o x 2}$ mice as our in vivo system. In both transorbital- and subdural-injected adCre; $N f 2^{\text {flox2/flox2 }}$ mice, the $N f 2^{\Delta 2}$ allele was PCR-amplified in the leptomeninges proximal to the injection site (Fig. 2A). Nf2 gene inactivation in arachnoidal cells was also confirmed by immunohistochemical analysis using specific anti-merlin polyclonal antibodies. Loss of merlin expression was observed in arachnoidal cells covering the trigeminal nerve in the proximity of the adCre (transorbital) injection site (Fig. 1C,D). Scattered regions of merlin-positive arachnoidal cells were also found in areas distant from the injection site. Altogether, these data indicate that the adCre virus transduces cells in the neuraxis by diffusing through the CSF after injection and that it efficiently induces $N f 2$ gene inactivation by Cre/loxP recombination.

\section{Disruption of Nf2 in arachnoidal cells promotes meningioma development}

After adCre administration, two cohorts of 17 transorbital $N f 2^{\text {flox2/flox2 }}$ and 19 subdural $N f 2^{\text {flox2/flox2 }}$ mice were observed and the survival compared to that of 24 noninjected and nine adlacZ-injected $N f 2^{\text {flox } 2 / f l o x 2}$ mice over a period of $20 \mathrm{mo}$. The percentage of surviving transorbital- and subdural-injected adCre; $N f 2^{\text {flox2/flox2 }}$ mice was significantly reduced compared to that of adlacZ-injected and noninjected $N f 2^{\text {flox2/flox2 }}$ animals (log rank, $P<0.0001$ ) (Fig. 3).

Transorbital-injected adCre; $N f 2^{\text {flox2/flox2 }}$ mice developed meningeal tumors ( 4 of 14 mice; $29 \%$ ) emanating from the meninges of the skull base at a mean age of 11 mo. Similarly, subdural-injected adCre; $N f 2^{\text {flox } 2 / f l o x 2}$ mice also developed meningeal tumors 13 of 16 mice; $19 \%$ ) in the vicinity of the injection site over the cerebral convexity at mean age of 14 mo (Table 1). In contrast to human pathology, a marked female bias was not observed in meningioma development (female:male ratio of $2: 5)$.

As in humans, the most frequent histological meningioma subtypes observed in these mice were meningothelial, fibroblastic, and transitional (Fig. 4). Similar to human patients in whom histologically benign meningiomas may invade brain (Louis et al. 2000), one mouse tumor showed irregular groups of tumor cells infiltrating the adjacent cerebral parenchyma causing reactive astrogliosis (Fig. 4E-G).
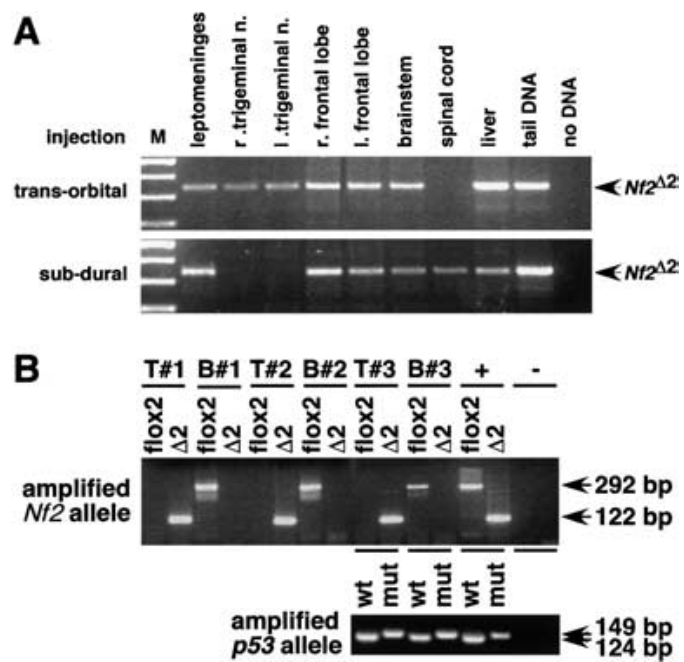

Figure 2. (A) Nf2 gene recombination in tissues of adCre; $N f 2^{\text {flox } 2 / f l o x 2}$ newborn mice. PCR analysis of genomic DNA samples from transorbital and subdural injected mice. (M) HaeIII-digested $\phi X 174$ DNA. Control tail DNA is from an $N f 2^{\Delta 2 / f l o x 2}$ mouse (1/1 ratio of $N f 2^{\text {flox } 2}$ and $N f 2^{\Delta 2}$ alleles). (B) Molecular analysis of $N f 2$ recombination in meningiomas arising in adCre injected $N f 2^{\text {flox2/flox2 }}(\# 1-2)$ and $N f 2^{\text {flox2/flox } 2}, p 53^{+/-}$mice (\#3). Tumor tissue (T) and adjacent brain (B) were microdissected and the $N f 2^{f l o x}, N f 2^{\Delta 2}, p 53^{+}$, and $p 53^{K O}$ alleles analyzed by semi-nested PCR. Control tail DNA $(+)$ is from an $N f 2^{\Delta 2 / f l o x 2}$ mouse (1/1 ratio of $N f 2^{f l o x 2}$ and $N f 2^{\Delta 2}$ alleles) and $p 53^{+/}$ control tail DNA is from the mouse in which the tumor was found. (-) No DNA. 

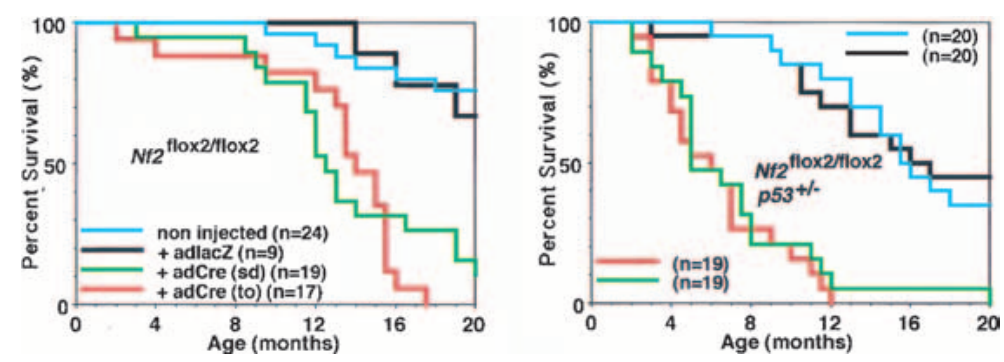

Figure 3. Survival curves of adCre injected $N f 2^{f l o x 2 / f l o x 2}, N f 2^{f l o x 2 / f l o x 2} ; p 53^{+/-}$, and control mice.

Analysis of merlin expression by immunohistochemistry showed loss of expression in two analyzed tumors (Fig. 4I). Remarkably, these two tumors were also immunonegative for Protein 4.1B expression (Fig. 4J), another Protein 4.1 family member implicated as a meningioma tumor suppressor (Gutmann et al. 2000). Further work will be required to determine the relationship between merlin loss and Protein 4.1B expression as well as the contribution of Protein 4.1B to meningioma pathogenesis in the mouse.

In contrast to transorbital-injected, subdural-injected adCre; $N f 2^{\text {flox } 2 / f l o x 2}$ mice ( 2 of $16 ; 13 \%$ ) also developed intraspinal meningiomas located in the thoracic region (Fig. 4K). This suggests that adCre diffusion in the CSF is higher following subdural infusion, thus reaching targets that are more distant from the injection site. Meningiomas were analyzed for $N f 2^{\text {flox } 2}$ allele recombination (Fig. 2B). Because tumors were only detected microscopically, laser capture microdissection was used to obtain pure tumor DNA samples. Two rounds of PCR with nested primers were necessary to detect a signal, probably because of the poor DNA quality following decalcification and paraffin embedding. The recombined $N f 2$ alleles were amplified in two out of two analyzed tumors. In contrast, the surrounding normal brain tissue showed no recombination of $N f 2^{\text {flox } 2}$ alleles. Taken together, these results indicate that Cre-lox $P$-mediated inactivation of both $N f 2^{\text {flox2 }}$ alleles is the rate-limiting step not only for schwannoma, but also for meningioma, development.
Schwann cell hyperplasia is considered an early manifestation of biallelic Nf2 inactivation and eventually results in schwannoma formation (Giovannini et al. 2000). Similarly, the first lesion associated with murine leptomeningeal tumorigenesis in this meningioma model was meningothelial proliferation that developed in the vicinity of the injection site in 33\% (transorbital plus subdural) of adCre; $N f 2^{\text {flox } 2 / f l o x 2}$ mice (Fig. 4M) and was not observed in adlacZinjected and in $\mathrm{Nf}^{+/-}$mice. Histologically, this lesion is composed of sheaths of spindle and polygonal cells without obvious perivascular aggregates and differs from meningioangiomatosis occasionally seen in NF2 patients (Stemmer-Rachamimov et al. 1997). Meningothelial proliferation in the adCre-Nf2 conditional knockout mice was limited to leptomeninges and the cerebral cortex was not involved.

No signs of inflammation were found in adlacZ/adCre-injected mice at the time of sacrifice; it is likely that neonatal adenovirus injection prevents an immune response to the virus (Kass-Eisler et al. 1994). Hydrocephalus was observed in $43 \%$ (transorbital plus subdural) of adCre; $N f 2^{f l o x 2 / f l o x 2}$ mice, including the two mice with intraspinal meningioma. In contrast, only one adlacZinjected mouse developed hydrocephalus. Thus, neither the scar at the site of injection nor a hypothetical immune reaction against adenovirus within the subdural space explains the hydrocephalus. In one case, an osteosarcoma emanating from a vertebral bone was found associated with hydrocephalus due to spinal cord compression. Meningothelial proliferation impeding CSF flow and causing progressive ventricular dilation is one possible etiology for the hydrocephalus observed in adCre; $N f 2^{\text {flox2/flox2 }}$ mice. A similar mechanism of hydrocephalus formation has been postulated for immunocompromised mice with intracranial meningioma xenografts exhibiting leptomeningeal involvement (McCutcheon et al. 2000).

No tumors were found in the ventricles or in the spinal cord. In particular, no ependymomas (a less common NF2-associated tumor) were detected. Indeed, analysis of the topography of adlacZ-transduced areas did not show

Table 1. Summary of the phenotypic consequences of adCre injection in $\mathrm{Nf2} 2^{\text {flox } 2 / \text { flox } 2}$ and $\mathrm{Nf2}{ }^{\text {flox } 2 / f l o x 2} ; \mathrm{p} 53^{+/-}$mice

\begin{tabular}{|c|c|c|c|c|}
\hline & $\begin{array}{l}\text { adCre; } N \text { ff } 2^{\text {flox } 2 / f l o x 2} \\
\text { t.o. }(n=14)\end{array}$ & $\begin{array}{l}\text { adCre; } N f 2^{\text {flox } 2 / f l o x 2} \\
\text { s.d. }(n=16)\end{array}$ & $\begin{array}{c}\text { adCre;Nf2 } 2^{\text {flox } 2 / f l o x 2} ; p 53^{+/-} \\
\text {t.o. }(n=18)\end{array}$ & $\begin{array}{c}\text { adCre; } N f 2^{\text {flox } 2 / f l o x 2} ; p 53^{+/-} \\
\text {s.d. }(n=15)\end{array}$ \\
\hline Phenotypic abnormality & $\mathrm{n}(\%)$ & $\mathrm{n}(\%)$ & $\mathrm{n}(\%)$ & $\mathrm{n}(\%)$ \\
\hline Meningioma (intracranial) & $4^{a}(29 \%)$ & $3(19 \%)$ & $2^{\mathrm{b}, \mathrm{c}}(11 \%)$ & 0 \\
\hline Meningioma (intraspinal) & 0 & $2(13 \%)$ & 0 & $2(13 \%)$ \\
\hline Meningothelial proliferation & $5(36 \%)$ & $5(31 \%)$ & $4(22 \%)$ & $1(7 \%)$ \\
\hline MPNST & 0 & 0 & $1(6 \%)$ & 0 \\
\hline Schwann cell hyperplasia & $3(21 \%)$ & 0 & $1(6 \%)$ & 0 \\
\hline Osteoma & $10(71 \%)$ & $14(88 \%)$ & $10(56 \%)$ & $11(73 \%)$ \\
\hline Osteosarcoma (peripheral) & 0 & $1(6 \%)$ & $1(6 \%)$ & $1(7 \%)$ \\
\hline $\begin{array}{l}\text { Osseous metaplasia (trigeminal } \\
\text { nerve) }\end{array}$ & $4(29 \%)$ & 0 & $1(6 \%)$ & 0 \\
\hline Pituitary adenoma & 0 & 0 & 0 & $1(7 \%)$ \\
\hline Sarcoma (at injection site) & 0 & 0 & $14^{\mathrm{d}}(78 \%)$ & $14^{\mathrm{e}}(93 \%)$ \\
\hline Liver tumor & $3(21 \%)$ & $3^{f}(19 \%)$ & $2^{g}(11 \%)$ & $2^{\mathrm{h}}(13 \%)$ \\
\hline Hydrocephalus & $8(57 \%)$ & $5(31 \%)$ & $10(56 \%)$ & $7(47 \%)$ \\
\hline
\end{tabular}

${ }^{\mathrm{a}} N f 2 \Delta 2(2 / 2) ;{ }^{\mathrm{b}} N f 2 \Delta 2(1 / 1) ;{ }^{\mathrm{c}} p 53 \mathrm{LOH}-(1 / 1) ;{ }^{\mathrm{d}} N f 2 \Delta 2$ (10/10); $p 53 \mathrm{LOH}+(10 / 10) ;{ }^{\mathrm{e}} N f 2 \Delta 2(10 / 10) ; p 53 \mathrm{LOH}+(10 / 10) ;{ }^{\mathrm{f}} N f 2 \Delta 2(2 / 2) ;{ }^{\mathrm{g}} N f 2 \Delta 2$ (2/2); p53 LOH- (2/2); ${ }^{\mathrm{h}} \mathrm{N} f 2 \Delta 2$ (2/2); p53 LOH- (2/2). t.o., Transorbital; s.d. subdural. 

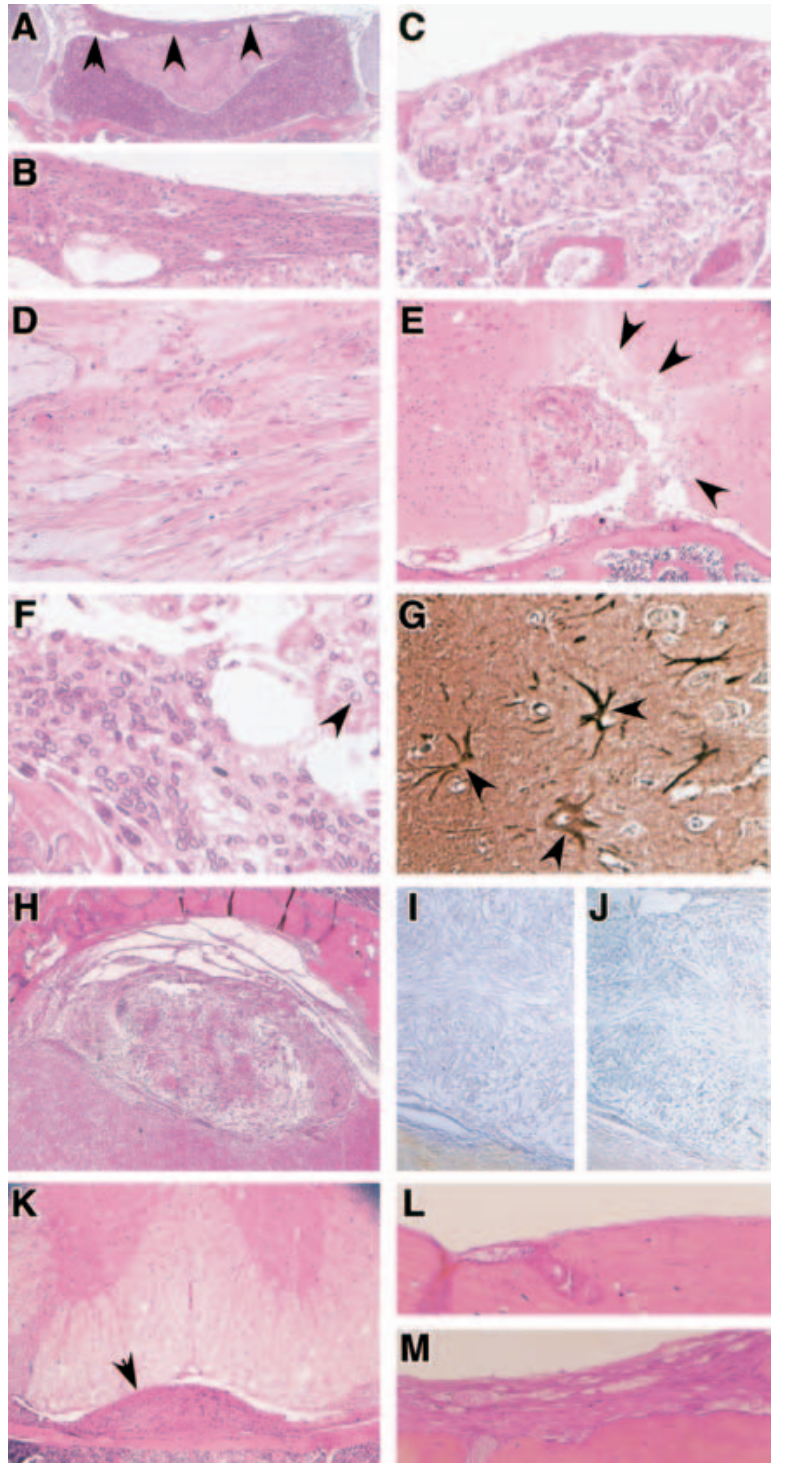

Figure 4. Meningiomas in mice show histological hallmarks of human meningiomas. Histology of meningiomas in adCre-injected $N f 2^{\text {flox } 2 / f l o x 2}(A, B, D-K)$ and $N f 2^{\text {flox } 2 / f l o x 2} ; p 53^{+/-}(C)$ mice. Sections are stained with haematoxilin and eosin. (A) Transitional meningioma (arrowheads) on the diaphragma sellae; $(B)$ magnification of the tumor in $A ;(C)$ meningothelial meningioma in the supra trigeminal nerve region. Tumor cells form lobules, which are surrounded by thin collagenous septae. Numerous concentric onion bulb structures and whorl formation are observed; $(D)$ fibroblastic meningioma with fascicular arrangements. Spindle-shaped cells form parallel and interlacing bundles on a matrix abundant in collagen and reticulin; $(E)$ menigothelial meningioma. Irregular calcified and ossified masses are present. Arrows indicate areas of brain invasion with $(F)$ typical meningothelial tumor cells infiltrating the adjacent cerebral parenchyma. Cells are largely uniform with oval nuclei that on occasion show central clearing (arrowhead); $(G)$ GFAP staining showing reactive astrocytes (arrowheads) in the proximity of tumor invasion; $(H)$ transitional meningioma showing loss of merlin $(I)$ and protein 4.1B $(J)$ expression; $(K)$ intraspinal meningioma (arrowhead) located in the thoracic region; $(L)$ normal meninges at the adlac $Z$ injection site in an $N f 2^{\text {flox2/flox2 }}$ mouse, and $(M)$ meningothelial proliferation at the adCre injection site in an $N f 2^{\text {flox2/flox } 2}$ littermate.

blue staining of cells layering the central canal (Fig. 1B), a frequent site of ependymoma formation in humans. Schwann cell hyperplasia of the trigeminal ganglion ip- silateral to the injection site was found in transorbitalinjected adCre; $N f 2^{\text {flox } 2 / f l o x 2}$ mice (3 of $14 ; 21 \%$ ), but never in subdural-injected mice, where adCre does not reach the trigeminal nerves. Osseous metaplasia developing within the trigeminal ganglion ipsilateral to the injection site was found in transorbital-injected adCre; $N f 2^{\text {flox } 2 / f l o x 2}$ mice (4 of 14; $29 \%$ ). Osteomas were frequently observed at the site of adCre injection, but were never observed in adlacZ-injected mice. Osseous metaplasia and osteoma are presumably induced by biallelic $N f 2$ inactivation in a neural crest precursor cell, as observed in conditional P0 Nf2 conditional knockout mice (Giovannini et al. 2000). Liver tumors (three hepatocellular carcinoma and three choloangiocarcinoma) occured in 6 of $30(20 \%)$ (transorbital plus subdural) adCre; $N f 2^{\text {flox } 2 / f l o x 2}$ mice (Table 1 ) at a mean age of 15 mo. The role of Nf2 loss in malignant bone and liver tumor development has been documented previously in Nf2 hemizygous mice (McClatchey et al. 1998). No bone or liver tumors were found in the adlacZ; Nf2 flox2/flox2 mice.

\section{Additional hemizygosity for p53 does not increase the rate of meningioma development in adCre; $\mathrm{Nf} 2^{\text {flox } 2 / \text { flox } 2}$ mice}

The incomplete penetrance of the meningioma phenotype suggests that additional epigenetic or genetic events are required for tumor development. At present, we have no evidence of strain-specific effects on Nf2-related tumor development (meningiomas are rarely observed in wild-type mice of any genetic background; Morgan et al. 1984), as both our schwannoma and meningioma models were generated in a mixed FVB/Nx129/Ola genetic background. Further studies will be necessary to determine if strain-specific effects modify the tumor spectrum in these $N f 2$ conditional mutant mice, as described for $N f 1$ (Reilly et al. 2000). Mutations of other tumor suppressor genes might cooperate with an Nf2 mutation to promote or accelerate tumorigenesis. Mice carrying mutations of Nf2 and p53 in cis rapidly develop multiple osteosarcomas and fibrosarcomas (McClatchey et al. 1998), and one meningioma has been reported in a $p 53^{-/-}$mouse (Harvey et al. 1993). To investigate the potential cooperativity of Nf2 inactivation and a heterozygous $p 53$ mutation in meningioma formation, $N f 2^{\text {flox } 2 / f l o x 2} ; p 53^{+/-}$mice were injected with adCre. After administration of adCre, two cohorts of 19 transorbital Nf2 flox $/$ flox 2 ; $553^{+/-}$and 19 subdural $N f 2^{\text {flox2/flox } 2} ; p 53^{+/-}$mice were observed over a period of $20 \mathrm{mo}$.

The survival of adCre; $N f 2^{\text {flox } 2 / f l o x 2} ; p 53^{+/-}$mice was significantly reduced compared to that of adCre; $N f 2^{\text {flox2/flox2 }}$ and 20 adlacZ;Nf2 flox2/flox2 $p 53^{+/-}$animals (log rank, $P<0.0001$ ) (Fig. 3). This reduced viability was attributable to the early development (mean age, $5.5 \mathrm{mo}$ ) of highly aggressive sarcomas at the transorbital (14 of 18 ; $78 \%$ ) or subdural (14 of $15 ; 93 \%$ ) injection site (Table 1 ). Sarcoma development at the site of injection was presumably attributable to the local adCre extravasation during injection, resulting in Cre-mediated Nf2 inactivation and sarcomas of the fibrosarcoma, rhabdomyosarcoma, and osteosarcoma histological subtypes. All analyzed tumors displayed recombination of the $N f 2^{\text {flox } 2}$ alleles and loss of the wild-type $p 53$ allele (20 of 20 tested by Southern blot analysis; data not shown). These results are in agreement with those of McClatchey et al. (1998) 
describing sarcoma formation in $\mathrm{Nf2}^{+/-}{ }_{i} p 53^{+/-}$cis mice with loss of heterozygosity (LOH) for both $N f 2$ and p53. The rate of meningioma development was similar in transorbital- $(2$ of $18 ; 11 \%)$ or subdural-injected (2 of $15 ; 13 \%$ ) adCre; $N f 2^{\text {flox } 2 / f l o x 2} ; \mathrm{p}^{2} 3^{+/-}$mice (sex ratio female:male of $1: 1)$, which is not significantly different $\left(\chi^{2}, P=0.08\right)$ from the rate of meningioma development in adCre; $N f 2^{\text {flox } 2 / f l o x 2}$ mice. However, the average age of meningioma development was lower in

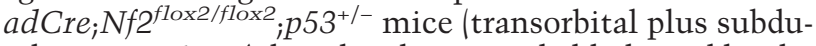
$\mathrm{ral}$, mean $=6 \mathrm{mo})$, but this data is probably biased by the premature sacrifice of mice that developed highly aggressive sarcomas. Histologically, these four meningiomas appeared as benign neoplasms, according to World Health Organization criteria (WHO I) (Kleihues and Sobin 2000). PCR analysis of one microdissected meningioma showed Nf2 exon 2 deletion but not $p 53$ LOH (Fig. 2B). Meningothelial proliferation and hydrocephalus developed in $15 \%$ and $52 \%$ (transorbital plus subdural) of

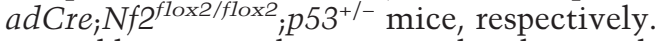

In addition, a malignant peripheral nerve sheath tumor (MPNST) emanating from the right trigeminal nerve was

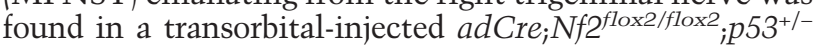
mouse ( 6.5 mo old). Synergy between $N f 2$ and p53 mutations in development of MPNSTs was also observed in P0Cre; $N f 2^{\text {flox } 2 / f l o x 2}{ }{\mathrm{p} 53^{+/-}}$mice that rapidly developed multiple tumors (E. Robanus-Maandag and M. Giovannini, unpubl.).

Liver tumors (two hepatocellular carcinoma and two cholangiocarcinoma) occured in 4 of $30(20 \%)$ transorbital- and subdural-injected mice with a mean age of 9 mo. All liver tumors displayed recombination of the $N f 2^{\text {flox } 2}$ alleles, but not $p 53$ LOH 14 of 4 tested by Southern blot analysis; data not shown), indicating that $N f 2$ and p53 mutations do not cooperate in liver tumor development. Six tumors were found that related exclusively to p53 loss (data not shown): One large pituitary macroadenoma and two osteosarcomas were found at locations not related to the injection site in three adCre; $N f 2^{\text {flox } 2 / f l o x 2} ;{\mathrm{p} 53^{+/-}}$mice. In addition, one glioblastoma and two osteosarcomas were found in three adlacZ; $N f 2^{\text {flox } 2 / f l o x 2} ; \mathrm{p5}^{+/-}$mice. These tumor types belong to the typical tumor spectrum of heterozygous $p 53$ mutant mice (Donehower et al. 1992). Genetic studies have suggested that inactivation of the retinoblastoma and p53 tumor suppressor genes are uncommon in meningiomas (Pykett et al. 1997; Tse et al. 1998). Our results suggest that in mice, as in humans, p53 gene inactivation is not a critical event for meningioma development. An additional event thought to be associated with malignant progression in meningiomas is loss of the $p 16^{I N K 4 A}$ tumor suppressor (Tse et al. 1998). The availability of meningioma-prone $N f 2$ conditional mutant mice will greatly facilitate the elucidation of additional genetic factors that influence meningioma development and progression.

\section{Conclusion}

The present mouse model demonstrates a successful alternative approach for developing animal models for human tumors where tissue-specific promoters are not available. Adenoviral delivery of Cre recombinase was initially attempted in vivo to develop a model for colorectal adenoma formation (Shibata et al. 1997). The application of this technology to central nervous system tumors has not been attempted previously. This strategy has the advantage of inducing Nf2 inactivation in a small population of cells that are surrounded by, and must outcompete, their normal counterparts in vivo. In this respect, adCre-based models probably mimic human cancer more accurately than strains in which a cancer-associated abnormality is induced simultaneously in an entire tissue. Direct evidence that the presence of wildtype competitor cells can modulate the ability of mutant cells to induce disease emerged recently from competitive repopulation experiments using $\mathrm{Nf1}^{-/-}$mutant hematopoietic cells (Zhang et al. 2001). AdCre inactivation of $N f 2$ was not only sufficient for meningioma formation, but also resulted in a similar spectrum of tumors originally observed in the conventional $\mathrm{Nf2}^{+/-}$mice on loss of the wild-type Nf2 allele (McClatchey et al. 1998; Giovannini et al. 2000). The present mouse model, which results in the development of one of the clinically relevant tumors in NF2, by a mechanism that is genetically similar to that observed in the human disease, provides a powerful new tool to study meningioma formation and progression as well as to evaluate potential novel therapeutic interventions prior to trials in humans.

\section{Materials and methods \\ Mice \\ $N f 2^{\text {flox2/+ }}$ mice on a mixed $129 / \mathrm{Ola}, \mathrm{FVB} / \mathrm{N}$ background were bred to $\mathrm{FVB} / \mathrm{N}$ mice for eight generations and then intercrossed to obtain $N f 2^{\text {flox2/flox } 2}$ mice (Giovannini et al. 2000). To obtain $N f 2^{\text {flox } 2 / f l o x 2}{ }^{2} p 53^{+/-}$ mice, $N f 2^{\text {flox } 2 / f l o x 2}$ mice were bred to $p 53^{+/-}$mice inbred in $129 / \mathrm{Sv}$ (Done- hower et al. 1992), and the resulting $\mathrm{Nf}^{\mathrm{flox} 2 /+}{ }_{;} \mathrm{PS}^{+/-}$mice bred to $N f 2^{\text {flox2/flox } 2}$ mice.}

\section{Injection of adenoviruses}

The Cre expression cassette was excised from pBS185 (Life Technologies) and inserted into the adenovirus shuttle vector pMA37 (gift from M. Latta-Mahieu, CNRS, Villejuif, France). Viral stocks were prepared and titered in 293 cells according to standard procedures (Stratford-Perricaudet et al. 1992). Mouse pups on postnatal day 2 were used for injections and anesthetized by hypothermia on ice. In the transorbital approach, a hand-held glass micropipette was gently introduced in the external corner of the right orbital cavity until the posterior bone wall was reached and perforated by application of a light pressure. In the subdural approach, the micropipette was lowered through the skin following a tangential axis in the right frontal region until perforation of the thin skull bone. Using a microinjector (Narashige, Japan), $3 \mu \mathrm{L}\left(3 \times 10^{8} \mathrm{pfu}\right)$ of the adCre or adlac $Z$ solutions were infused over the course of $1 \mathrm{~min}$ and the pipette was left in place for a further minute before removal to limit diffusion away from the site of release. Following injections, pups were kept in an isolator under an infrared heat lamp until active and showing no signs of respiratory distress.

Molecular analysis of tissues and tumors

Genomic DNA was extracted from various tissues and the recombined $N f 2^{\Delta 2}$ allele detected as described in Giovannini et al. (2000). Microdissection of tumors and of adjacent normal brain tissue was performed using a laser capture microdissection system (PALM). Dissected material was digested overnight with proteinase $\mathrm{K}$, heat inactivated and used directly in PCR reactions. $N f 2^{\text {flox } 2}, \mathrm{Nf} 2^{\Delta 2}, p 53^{+}$, and $p 53^{K O}$ alleles were amplified by semi-nested PCR (primer sequences and conditions available on request).

Histopathology and immunohistochemistry

Mice were sacrificed at the times indicated and a complete necropsy performed as described previously (Giovannini et al. 1999). To preserve the arachnoidal layer, the head was fixed in formalin in toto, decalcified, and sliced coronally before embedding in paraffin. Histological analysis, detection of $\beta$-galactosidase activity, and immunohistochemistry with 
affinity purified rabbit polyclonal antibodies against merlin $(1: 500$; WA30; Gutmann et al. 1997), DAL-1 (1:500; 3A1; Perry et al. 2000), and rat monoclonal anti-GFAP (1:100; Zymed) were performed as described in Giovannini et al. (2000).

\section{Acknowledgments}

We thank L.A. Donehower for $p 53^{-/-}$mice; CDTA (Orléans, France) for mouse housing; F. Amira, N. Gervais, L. Legres, and N. Hedrick for histotechnical assistance; A. Couvelard, C. Degott, D. Figarella, D. Louis, A. Perry, and J. Woodruff for discussion on the tumor phenotypes; P. Berthaud for help with microdissection; K. Shannon and L. Parada for critically reading the manuscript. DAL-1 antibody was generously provided by I. Newsham. This work was supported by Grants from the U.S. Army Medical Research and Materiel Command (DAMD17-00-1-0594 to M.G.), Ligue Nationale Française contre le Cancer (M.G.), Association pour la Recherche sur le Cancer (M.G.), and by grants from the National Institutes of Health (NS35848 and NS41520) to D.H.G.

The publication costs of this article were defrayed in part by payment of page charges. This article must therefore be hereby marked "advertisement" in accordance with 18 USC section 1734 solely to indicate this fact.

\section{References}

Donehower, L.A., Harvey, M., Slagle, B.L., McArthur, M.J., Montgomery, Jr., C.A., Butel, J.S., and Bradley, A. 1992. Mice deficient for p53 are developmentally normal but susceptible to spontaneous tumours. Nature 356: 215-221.

Evans, D.G., Huson, S.M., Donnai, D., Neary, W., Blair, V., Newton, V., Strachan, T., and Harris, R. 1992. A genetic study of type 2 neurofibromatosis in the United Kingdom. II. Guidelines for genetic counselling. J. Med. Genet. 29: 847852 .

Giovannini, M., Robanus-Maandag, E., Niwa-Kawakita, M., van der Valk, M., Woodruff, J.M., Goutebroze, L., Merel, P., Berns, A., and Thomas, G. 1999. Schwann cell hyperplasia and tumors in transgenic mice expressing a naturally occurring mutant NF2 protein. Genes \& Dev. 13: 978-986.

Giovannini, M., Robanus-Maandag, E., van der Valk, M., NiwaKawakita, M., Abramowski, V., Goutebroze, L., Woodruff, J.M., Berns, A., and Thomas, G. 2000. Conditional biallelic $\mathrm{Nf} 2$ mutation in the mouse promotes manifestations of human neurofibromatosis type 2. Genes \& Dev. 14: 1617-1630.

Gutmann, D.H., Giordano, M.J., Fishback, A.S., and Guha, A. 1997. Loss of merlin expression in sporadic meningiomas, ependymomas and schwannomas. Neurology 49: 267-270.

Gutmann, D.H., Donahoe, J., Perry, A., Lemke, N., Gorse, K., Kittiniyom, K., Rempel, S.A., Gutierrez, J.A., and Newsham, I.F. 2000. Loss of DAL-1, a protein 4.1-related tumor suppressor, is an important early event in the pathogenesis of meningiomas. Hum. Mol. Genet. 9: 1495-1500.

Harvey, M., McArthur, M.J., Montgomery, Jr., C.A., Bradley, A., and Donehower, L.A. 1993. Genetic background alters the spectrum of tumors that develop in p53-deficient mice. FASEB J. 7: 938-943.

Kass-Eisler, A., Falck-Pedersen, E., Elfenbein, D.H., Alvira, M., Buttrick, P.M., and Leinwand, L.A. 1994. The impact of developmental stage, route of administration and the immune system on adenovirus-mediated gene transfer. Gene Ther. 1: 395-402.

Kleihues, P. and Sobin, L.H. 2000. World Health Organization classification of tumors. Cancer 88: 2887.

Louis, D.N., Scheitauer, B.W., Budka, H., von Deimling, A., and Kepes, J.J. 2000. Meningiomas. In Pathology and genetics of tumours of the nervous system (ed. P. Kleihues and W.K. Cavenee), pp. 176-184. IARC Press, Lyon, France.

McClatchey, A.I., Saotome, I., Mercer, K., Crowley, D., Gusella,
J.F., Bronson, R.T., and Jacks, T. 1998. Mice heterozygous for a mutation at the Nf2 tumor suppressor locus develop a range of highly metastatic tumors. Genes \& Dev. 12: 11211133 .

McCutcheon, I.E., Friend, K.E., Gerdes, T.M., Zhang, B.M., Wildrick, D.M., and Fuller, G.N. 2000. Intracranial injection of human meningioma cells in athymic mice: An orthotopic model for meningioma growth. J. Neurosurg. 92: 306-314.

Morgan, K.T., Frith, C.H., Swenberg, J.A., McGrath, J.T., Zulch, K.J., and Crowder, D.M. 1984. A morphologic classification of brain tumors found in several strains of mice. I. Natl. Cancer Inst. 72: 151-160.

Perry, A., Cai, D.X., Scheithauer, B.W., Swanson, P.E., Lohse, C.M., Newsham, I.F., Weaver, A., and Gutmann, D.H. 2000 Merlin, DAL-1, and progesterone receptor expression in clinicopathologic subsets of meningioma: A correlative immunohistochemical study of 175 cases. I. Neuropathol. Exp. Neurol. 59: 872-879.

Pykett, M.J., Landers, J., and George, D.L. 1997. Expression patterns of the $\mathrm{p} 53$ tumor suppressor gene and the $\mathrm{mdm} 2$ protooncogene in human meningiomas. J. Neurooncol. 32: 39-44.

Reilly, K.M., Loisel, D.A., Bronson, R.T., McLaughlin, M.E., and Jacks, T. 2000. Nf1;Trp53 mutant mice develop glioblastoma with evidence of strain-specific effects. Nat. Genet. 26: 109-113.

Shibata, H., Toyama, K., Shioya, H., Ito, M., Hirota, M., Hasegawa, S., Matsumoto, H., Takano, H., Akiyama, T. Toyoshima, K., et al. 1997. Rapid colorectal adenoma formation initiated by conditional targeting of the Apc gene. Science 278: 120-123.

Stemmer-Rachamimov, A.O., Horgan, M.A., Taratuto, A.L., Munoz, D.G., Smith, T.W., Frosch, M.P., and Louis, D.N 1997. Meningioangiomatosis is associated with neurofibromatosis 2 but not with somatic alterations of the NF2 gene. J. Neuropathol. Exp. Neurol. 56: 485-489.

Stratford-Perricaudet, L.D., Makeh, I., Perricaudet, M., and Briand, P. 1992. Widespread long-term gene transfer to mouse skeletal muscles and heart. I. Clin. Invest. 90: 626-630.

Tohma, Y., Yamashima, T., and Yamashita, J. 1992. Immunohistochemical localization of cell adhesion molecule epithelial cadherin in human arachnoid villi and meningiomas. Cancer Res. 52: 1981-1987.

Tse, J.Y., Ng, H.K., Lo, K.W., Chong, E.Y., Lam, P.Y., Ng, E.K., Poon, W.S., and Huang, D.P. 1998. Analysis of cell cycle regulators: p16INK4A, pRb, and CDK4 in low- and highgrade meningiomas. Hum. Pathol. 29: 1200-1207.

Wang, Y., Krushel, L.A., and Edelman, G.M. 1996. Targeted DNA recombination in vivo using an adenovirus carrying the cre recombinase gene. Proc. Natl. Acad. Sci. 93: 39323936.

Zhang, Y., Taylor, B.R., Shannon, K., and Clapp, D.W. 2001. Quantitative effects of Nf1 inactivation on in vivo hematopoiesis. J. Clin. Invest. 108: 709-715. 


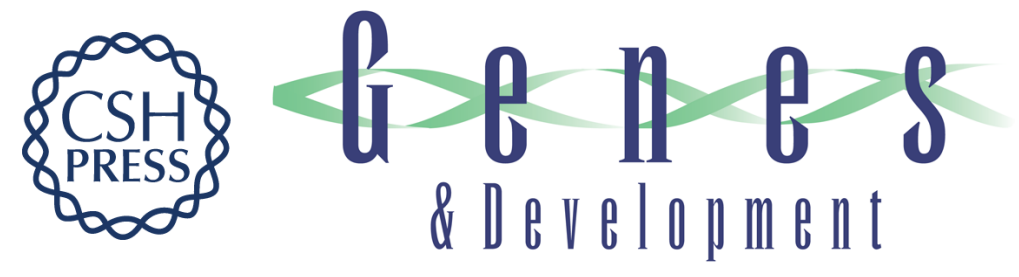

\section{Nf2 gene inactivation in arachnoidal cells is rate-limiting for meningioma development in the mouse}

Michel Kalamarides, Michiko Niwa-Kawakita, Hélène Leblois, et al.

Genes Dev. 2002, 16:

Access the most recent version at doi:10.1101/gad.226302

References This article cites 20 articles, 8 of which can be accessed free at: http://genesdev.cshlp.org/content/16/9/1060.full.html\#ref-list-1

License

Email Alerting

Receive free email alerts when new articles cite this article - sign up in the box at the top Service right corner of the article or click here.

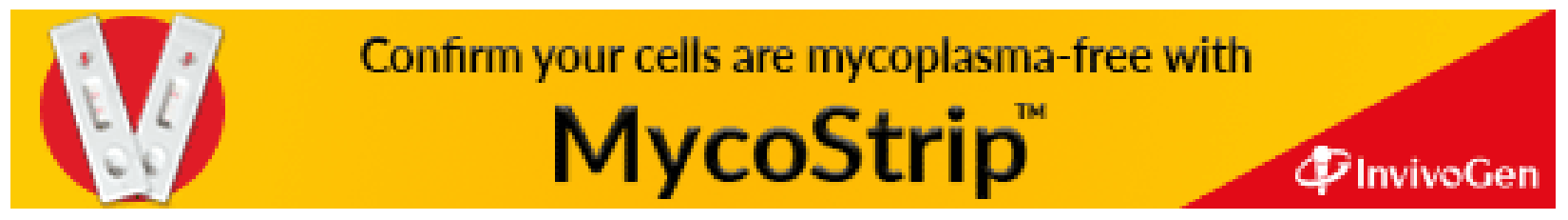

